\title{
РЕКОНСТРУКЦИЯ ФИЗИЧЕСКОГО ТИПА ПОЗДНЕСРЕДНЕВЕКОВЫХ КРЫМСКИХ ТАТАР КЕРЧЕНСКОГО ПОЛУОСТРОВА*
}

\begin{abstract}
В статье приводится комплексный палеоантропологический анализ населения, оставившего некрополь Биели (2. Керчь, Республика Крым). Большой интерес эта серия представляет в связи с изучением этногенеза крымских татар. В работе дается краниологическая характеристика позднесредневековых крымских татар. Приводятся реконструкции лица по черепу по методу М.М. Герасимова. Особое внимание уделено реконструированию физического облика данного населения. Выявлены высокая детская смертность и низкий показатель средней продолжительности жизни населения, что говорит о невысоком благополучии в изучаемой группе.
\end{abstract}

Ключевые слова: крымские татары, краниометрия, остеометрия, палеодемография

\section{Введение}

В мае-июле 2020 г. археологической экспедицией были проведены научные археологические исследования на памятнике археологии - поселение и некрополь Биели, входящего в полосу отвода и попадающего под разрушение в ходе строительства.

В настоящее время топоним Биели связан с урочищем, расположенным на Керченском полуострове в 1,5 км. к ЮЗ от пос. Октябрьское (адм. границы г. Керчь). В историческое время здесь существовало одноименное поселение, время его появления не установлено. В османский период истории региона рассматриваемая местность административно относилась к Орта - Керченскому кадылыку Кефинского каймаканства, однако в доступных османских фискальных документах поселение не фигурирует. Наиболее раннее упоминание о деревне Биелит присутствует относится к 1774 году.

Археологическими разведками 60 годов прошлого века В.В. Веселова и И.Т. Кругликовой в районе урочища Биели были отмечены археологические остатки, атрибутированные в качестве значительного средневекового (предположительно татарского) поселения, зафиксированного в источниках как «Октябрьское VII». В настоящее время памятник отождествляется с деревней Биели.

Боруцкая Светлана Борисовна - к.б.н., старший научный сотрудник кафедры антропологии биологического факультета, МГУ им. М.В. Ломоносова (119234 Москва, Ленинские горы, 1/12) Эл. почта: vasbor1@yandex.ru

Васильев Сергей Владимирович - д.и.н., главный научный сотрудник Центра физической антропологии, Институт этнологии и антропологии РАН (119934, Москва, Ленинский пр. 32-а). Эл. почта: vasbor1@yandex.ru

* Работа выполнена при финансовой поддержке гранта РФФИ № 18-09-00429 
Данная работа является продолжением палеоантропологического исследования крымскотатарских некрополей позднесредневекового и нового времени (Васильев 2018; Васильев, Боруцкая 2018; Иванов, Васильев 2019).

\section{Материалы и методы}

Определение пола в нашей работе проводилось у индивидов старше 15 лет согласно традиционным методам антропологии с учетом развития морфологических особенностей черепа и посткраниального скелета (Добряк 1960; Алексеев, Дебец 1964; Алексеев 1966). В некоторых случаях также использовались измерительные признаки черепа согласно методике В.И. Пашковой (Пашкова 1958). Методика расчета различных показателей демографии группы базировалась на программе палеодемографического исследования, изложенной в работе Д.В. Богатенкова с соавторами (Богатенков 2003).

Исследование черепов проводилось по классической краниологической программе (Алексеев, Дебеи 1964), а посткраниальных скелетов по программе, изложенной в пособии В.П.Алексеева (Алексеев 1966).

\section{Результаты и обсуждение}

\section{Палеодемография.}

В результате археологических раскопок было вскрыто 96 погребений. К сожалению, план проводимых работ не позволил охватить всю площадь кладбища, но большая часть территории все же была исследована. Из 96-ти костяков удалось идентифицировать по полу и возрасту 94 индивида. Два скелета были крайне фрагментарны. Таким образом, в палеодемографическом анализе были задействованы данные по 94 индивидам. Мы понимаем, что, во-первых, кладбище было вскрыто не целиком и, во-вторых, что датировка кладбища - 17-18 вв. может соответствовать как одному, так и двум столетиям формирования некрополя. Жалко, что индивидов было меньше даже 100, особенно если кладбище формировалось более столетия, хотя цифра 94 индивида тоже достаточно велика. Поэтому, проводя расчет палеодемографических индексов, мы понимали некоторую условность полученных результатов.

Половозрастные определения мы проводили с учетом ряда методик (Алексеев 1966; Дебеи, Алексеев 1964; Пашкова 1963; Добряк 1960 и др.). Все индивиды были распределены в когорты по пятилетним интервалам. Палеодемографические индексы рассчитывались согласно методике Angel (1969) (Angel 1969, u̧ит. по Богатенкову 2003). Результаты распределения индивидов по возрастным когортам (Dx), определения процентного соотношения индивидов по возрасту $(\mathrm{Cx})$ в целом для группы процент дожития до соответствующей возрастной когорты (Lx) и вероятность смерти в соответствующей когорте (qх) представлены в таблице 1. 
Таблица 1

\section{Некоторые палеодемографические показатели для группы крымских татар из Биели}

\begin{tabular}{|c|c|c|c|c|}
\hline Возрастная когорта & Dx (чел.) & $\mathrm{Cx}(\%)$ & Lx (\%) & $\mathbf{q x}$ \\
\hline $0-1$ лет & 5 & 5,320 & 100 & 0,053 \\
\hline $0-5$ лет & 19 & 20,210 & 100 & 0,202 \\
\hline 5-10 лет & 14 & 14,894 & 79,790 & 0,187 \\
\hline $10-15$ лет & 3 & 3,190 & 64,896 & 0,049 \\
\hline $15-20$ лет & 6 & 6,382 & 61,706 & 0,103 \\
\hline $20-25$ лет & 8 & 8,510 & 55,324 & 0,154 \\
\hline $25-30$ лет & 15 & 15,96 & 46,814 & 0,341 \\
\hline $30-35$ лет & 15 & 15,96 & 30,854 & 0,517 \\
\hline 35-40 лет & 7 & 7,450 & 14,894 & 0,500 \\
\hline $40-45$ лет & 6 & 6,380 & 7,444 & 0,857 \\
\hline $45-50$ лет & 0 & 0 & 1,064 & 0 \\
\hline $50+$ лет & 1 & 1,064 & 1,064 & 1,000 \\
\hline$\sum$ & 94 & 100 & & \\
\hline
\end{tabular}

В таблице 2 представлены итоги распределения по возрастным когортам и расчета процентного распределения по возрастам мужчин и женщин по-отдельности.

Таблица 2

\section{Распределения по возрастным когортам мужчин и женщин группы из Биели (17-18 вв)}

\begin{tabular}{l|c|c|c|c}
\hline Возрастная когорта & Dх (чел.) & Cx (\%) & Dx (чел.) & Cx (\%) \\
\hline & \multicolumn{2}{|c|}{ мужчины } & \multicolumn{2}{|c}{ женщины } \\
\hline $15-20$ лет & 2 & 7,41 & 4 & 12,90 \\
$20-25$ лет & 3 & 11,11 & 5 & 16,13 \\
$25-30$ лет & 5 & 18,52 & 10 & 32,26 \\
$30-35$ лет & 8 & 29,63 & 7 & 22,58 \\
$35-40$ лет & 7 & 25,93 & 0 & 0 \\
\hline $40-45$ лет & 2 & 7,41 & 4 & 12,90 \\
\hline $45-50$ лет & 0 & 0 & 0 & 0 \\
\hline $50+$ лет & 0 & 0 & 1 & 3,23 \\
\hline$\sum$ & 27 чел. & $100 \%$ & 31 чел. & $100 \%$ \\
\hline
\end{tabular}

Таким образом, группу составили 27 мужчин, 31 женщина, 36 детей и подростков до 15 лет. Процент детской смертности (PCD) составил 38,3\%, что является не катастрофическим, но высоким показателем. При этом более 5\% населения умирало в первый год жизни. Относительно всех детей этот показатель составил почти 13,9\%, что является низкой величиной. При этом большинство детей умирало в возрасте 0-5 лет $52,8 \%$, то есть больше половины. Средний возраст смерти детей составил 5,28 лет.

Пик смертности в группе приходится на первую возрастную когорту, 0-5 лет. Последующие пики смертности наблюдаются в целом в группе уже у взрослых в возрас- 
те 25-30, 30-35 лет, то есть в период наиболее интенсивной трудовой деятельности.

Процентное соотношение мужчин и женщин группы (PSR) соответствует $46,55 \%-53,45 \%$. То есть, женщин было намного больше. Обычно наблюдается иное соотношение.

У мужчин пик смертности приходится на интервалы 30-35 лет и 35-40 лет. То есть, это возраст примерно на когорту старше, чем получилось для всей группы в среднем. Пик смертности женщин группы приходится на 25-30 лет, то есть на время интенсивной трудовой деятельности и репродуктивной активности.

Процент индивидов в финальной возрастной когорте, С50+ лет, составил всего $1,06 \%$, что является очень низким показателем, отражающим демографическое неблагополучие в данной группе.

Средняя продолжительность жизни в группе крымских татар из Биели (или средний возраст смерти в группе, (А)) составила 20,7 лет. Показатель не высокий.

Таким образом, в целом можно говорить о невысоком демографическом благополучие в группе крымских татар из Биели, о чем свидетельствуют такие показатели, как высокий процент детской смертности, крайне низкая представительность финальной возрастной когорты (причем это только женщины), низкий показатель средней продолжительности жизни населения.

\section{Краниометрия}

Нами было изучено по стандартной краниологической программе 10 черепов, 5 из которых принадлежали мужчинам и 5 - женщинам. Наиболее важные измерения и указатели, характеризующие форму черепа и его составляющих, приведены в таблицах 3 и 4.

Таблица 3

\section{Краниометрические характеристики мужских черепов из некрополя Биели}

\begin{tabular}{|c|c|c|c|c|}
\hline № & Признак & $\mathbf{N}$ & $\mathbf{X}$ & $\mathbf{S}$ \\
\hline 1 & Продольный диаметр & 5 & 177,6 & 5,92 \\
\hline 8 & Поперечный диаметр & 5 & 143,8 & 3,84 \\
\hline 17 & Высотный диаметр & 5 & 136 & 4,0 \\
\hline 5 & Длина основания черепа & 5 & 100,8 & 2,96 \\
\hline 9 & Наименьшая ширина лба & 5 & 98,6 & 3,52 \\
\hline 10 & Наибольшая ширина лба & 5 & 132,8 & 2,96 \\
\hline 11 & Ширина основания черепа & 5 & 127,2 & 3,76 \\
\hline 12 & Ширина затылка & 5 & 110,6 & 4,08 \\
\hline 45 & Скуловой диаметр & 5 & 136,4 & 5,12 \\
\hline 40 & Длина основания лица & 5 & 100,4 & 3,12 \\
\hline 48 & Верхняя высота лица & 5 & 71,9 & 1,92 \\
\hline 43 & Верхняя ширина лица & 5 & 107,4 & 2,16 \\
\hline 46 & Средняя ширина лица & 5 & 100 & 2,80 \\
\hline 55 & Высота носа & 5 & 50,9 & 20,8 \\
\hline 54 & Ширина носа & 5 & 25,2 & 1,56 \\
\hline
\end{tabular}


Таблица 3 (продолжение)

\begin{tabular}{|c|c|c|c|c|}
\hline № & Признак & $\mathbf{N}$ & $\mathbf{X}$ & $\mathbf{S}$ \\
\hline 51 & Ширина орбиты от мф. & 5 & 40,86 & 1,29 \\
\hline 52 & Высота орбиты & 5 & 32,26 & 0,55 \\
\hline 77 & Назо-молярный угол & 5 & 141,2 & 2,56 \\
\hline$<\mathrm{zm}$ & Зиго-максиллярный угол & 5 & 128,2 & 2,24 \\
\hline $8 / 1$ & Черепной указатель & 5 & 81,12 & 3,34 \\
\hline \multirow[t]{2}{*}{$48 / 45$} & Верхний лицевой указатель & 5 & 52,8 & 2,08 \\
\hline & Симотический указатель & 5 & 41,8 & 3,48 \\
\hline $54 / 55$ & Носовой указатель & 5 & 49,54 & 2,83 \\
\hline $52 / 51$ & Орбитный указатель & 5 & 79,02 & 1,85 \\
\hline
\end{tabular}

Таблица 4

\section{Краниометрические характеристики женских черепов из некрополя Биели}

\begin{tabular}{|c|c|c|c|c|}
\hline № & Признак & $\mathbf{N}$ & $\mathbf{X}$ & $\mathbf{S}$ \\
\hline 1 & Продольный диаметр & 5 & 172,6 & 5,28 \\
\hline 8 & Поперечный диаметр & 5 & 142 & 4,0 \\
\hline 17 & Высотный диаметр & 5 & 128,4 & 1,28 \\
\hline 5 & Длина основания черепа & 5 & 96,8 & 1,76 \\
\hline 9 & Наименьшая ширина лба & 5 & 99 & 4,4 \\
\hline 10 & Наибольшая ширина лба & 5 & 129,6 & 3,68 \\
\hline 11 & Ширина основания черепа & 5 & 129,2 & 3,36 \\
\hline 12 & Ширина затылка & 5 & 109,8 & 3,36 \\
\hline 45 & Скуловой диаметр & 5 & 132,6 & 1,84 \\
\hline 40 & Длина основания лица & 5 & 95,8 & 1,84 \\
\hline 48 & Верхняя высота лица & 5 & 67,4 & 1,84 \\
\hline 43 & Верхняя ширина лица & 5 & 107,2 & 1,92 \\
\hline 46 & Средняя ширина лица & 5 & 99,2 & 2,96 \\
\hline 55 & Высота носа & 5 & 49,54 & 1,23 \\
\hline 54 & Ширина носа & 5 & 24,9 & 1,92 \\
\hline 51 & Ширина орбиты от мф. & 5 & 39,42 & 1,38 \\
\hline 52 & Высота орбиты & 5 & 32,44 & 1,13 \\
\hline 77 & Назо-молярный угол & 5 & 142,8 & 1,44 \\
\hline$<\mathrm{zm}$ & Зиго-максиллярный угол & 5 & 136,6 & 2,32 \\
\hline $8 / 1$ & Черепной указатель & 5 & 82,32 & 2,10 \\
\hline \multirow[t]{2}{*}{$48 / 45$} & Верхний лицевой указатель & 5 & 50,84 & 1,89 \\
\hline & Симотический указатель & 5 & 35,16 & 4,75 \\
\hline $54 / 55$ & Носовой указатель & 5 & 50,24 & 3,29 \\
\hline $52 / 51$ & Орбитный указатель & 5 & 82,44 & 3,83 \\
\hline
\end{tabular}

Череп исследованных крымских татар XVII - начала XVIII веков может быть описан как укороченный и широкий, брахикранный, форма сверху в большинстве 
случаев овоидная. Череп средней высоты в абсолютных размерах. Вообще, большинство абсолютных размеров мозговой коробки попадают в категорию средних, за рядом нескольких исключений. Например, наименьшая и наибольшая ширина лба имеют большие значения.

Лицевая часть черепа мезогнатная, среднеширокая и средневысокая, по верхнелицевому указателю - мезенная. Углы горизонтальной профилировки входят в категорию средних и малых, т.е. лицо по европеоидным меркам хорошо профилировано. Орбиты низкие и среднеширокие (хамеконхные). В абсолютных размерах нос средний (мезоринный).

На графической реконструкции лица по черепу по методу М.М. Герасимова отчетливо видны все описанные морфологические характеристики (Рис. 1, 2). Автор реконструкции Алехина О.И.

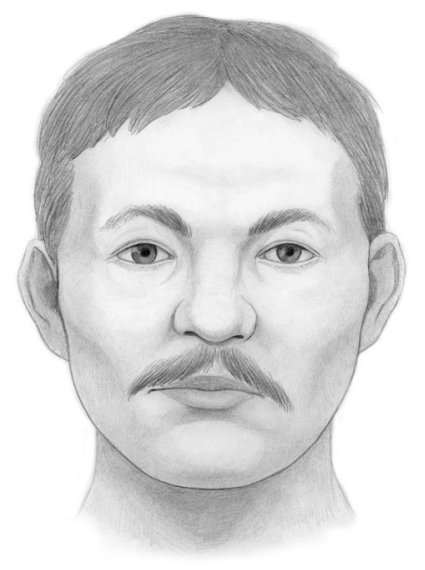

Рис. 1. Графическая реконструкция мужчины из погребения 21 (анфас). Автор Алехина О.И.

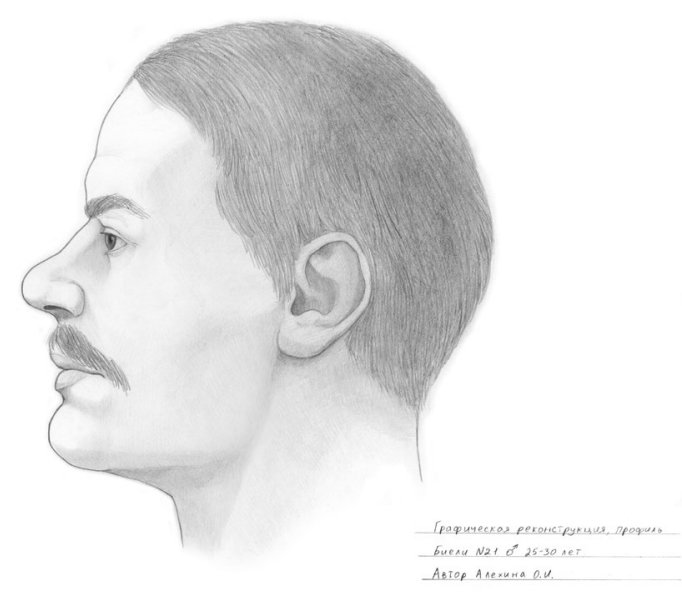

Рис. 2. Графическая реконструкиия мужчины из погребения 21 (профиль). Автор Алехина О.И.

Череп исследованных жительниц Крыма (некрополь Биели) может быть описан как укороченный и широкий, брахикранный, форма сверху в большинстве случаев овоидная. Череп средневысокий в абсолютных размерах. Вообще, большинство абсолютных размеров мозговой коробки попадают в категорию малых и средних, за рядом нескольких исключений. Например, ширина затылка и ширина основания черепа имеют большие значения.

Лицевая часть черепа мезогнатная, среднеширокая и средневысокая, по верхнелицевому указателю - мезенная. Углы горизонтальной профилировки входят в категорию средних, т.е. лицо по европеоидным меркам несколько уплощенно. Орбиты достаточно высокие - мезоконхные. В абсолютных размерах нос широкий (хамерринный), со средневыступающим переносьем.

Графическая реконструкция лица женщины по черепу по методу М.М. Герасимова отражает все вышеперечисленные характеристики (Рис. 3, 4). Автор реконструкции Алехина О.И. 


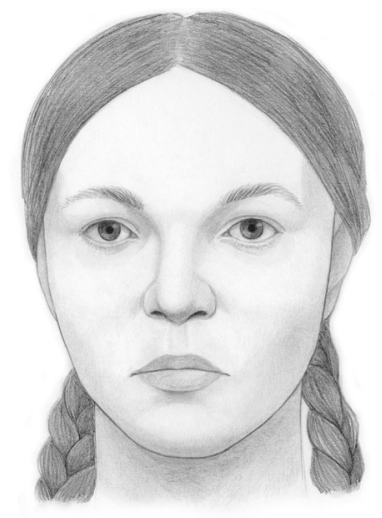

Рис. 3. Графическая реконструкиия женшины из погребения 24 (анфас). Автор Алехина О.И.

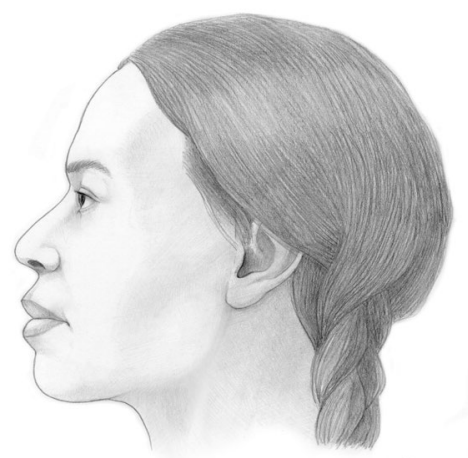

Рис. 4. Графическая реконструкиия женшины из погребения 24 (профиль). Автор Алехина О.И.

\section{Остеометрия}

Нами было измерено 13 мужских и 11 женских скелетов. Далее были рассчитаны индексы пропорций конечностей и некоторые показатели телосложения, индексы массивности (прочности) длинных костей конечностей и некоторые особенности этих костей в разных ярусах, рассчитана прижизненная длина тела. Некоторые индексы были сопоставлены с данными размаха их вариаций у человека современного типа (Алексеев 1966; Рогинский, Левин 1966; Хрисанфова 1968). Результаты расчета индексов пропорций и прижизненной длины тела представлены в таблицах 5 и 6.

Таблица 5

Индексы пропорций, некоторые показатели скелета и рассчитанная прижизненная длина тела у мужчин из крымско-татарского некрополя Биели

\begin{tabular}{|c|c|c|c|c|c|}
\hline Индексы & $\mathbf{n}$ & $\mathbf{X}$ & $\min$ & $\max$ & Размах вариаций \\
\hline 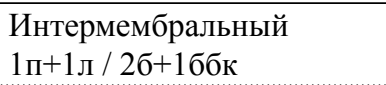 & 11 & 71,746 & 68,45 & 73,12 & $60-84$ \\
\hline Плече-бедренный $1 / 2$ & 12 & 73,29 & 70,98 & 75,97 & $68,8-72,9$ \\
\hline Луче-большеберцовый $1 / 1$ & 12 & 70,03 & 64,01 & 73,14 & $62-71$ \\
\hline Луче-плечевой $1 / 1$ & 13 & 76,82 & 73,56 & 80,68 & $71-82$ \\
\hline Берцово-бедренный $1 / 2$ & 11 & 80,45 & 77,32 & 85,13 & $77,3-86,6$ \\
\hline Ширина плеч (см) & 12 & 36,09 & 32,00 & 40,00 & \\
\hline Плече-ростовой & 12 & 22,15 & 20,08 & 23,75 & \\
\hline Ширина таза (см) & 11 & 27,56 & 24,50 & 29,70 & \\
\hline Тазовый & 5 & 76,94 & 73,05 & 82,82 & \\
\hline Тазо-ростовой & 11 & 16,92 & 14,74 & 18,08 & \\
\hline $\begin{array}{l}\text { Реконструированная } \\
\text { длина тела (см) }\end{array}$ & 13 & $162,75 \mathrm{~cm}$ & 157,8 & 168,4 & \\
\hline
\end{tabular}


Интермембральный индекс у мужчин имеет средние значения.

Плече-бедренный индекс оказался величиной средней, выше среднего и ультравысокой, что соответствует (по большей части в группе мужчин Биели) относительно удлиненным плечевым отделам рук.

Луче-берцовый указатель имеет самые разные значения среди мужских индивидов из Биели.

Согласно луче-плечевому (брахиальному) индексу примерно у половины мужчин группы были немного укороченными предплечья, у остальных - немного удлиненные.

То же самое можно сказать и относительно длины голеней по сравнению с бедром. При этом индивидов с выраженно удлиненными голенями не обнаружено.

Мужчины из группы Биели сильно различались по абсолютной ширине плеч. Встречаются индивиды и с крайне узкими плечами (минимум - 32 см), и с довольно широкими - до 40 см. Интересно, что относительная ширина плеч, согласно плече-ростовому индексу, у всех мужчин почти одинаковая. Самые узкие плечи были у самых низкорослых мужчин, широкие плечи - у наиболее высокорослых.

Мужчины из Биели также сильно различались и по ширине таза. В группе присутствовали как выраженно узкотазые индивиды, так и широкотазые. Причем в данном случае размер таза не был сопряжен с ростом индивида, никак от этого не зависел.

Среди пяти индивидов, для которых удалось определить тазо-ростовой индекс и соответственно относительную высоту таза, только у одного таз был высоким, как и положено мужчинам. У остальных четырех людей таз был низким, как должно быть обычно у женщин. С длиной тела это так же не было сопряжено.

Таблица 6

Индексы пропорций, некоторые показатели скелета и рассчитанная прижизненная длина тела у женщин из крымско-татарского некрополя Биели

\begin{tabular}{|c|c|c|c|c|c|}
\hline Индексы & $\mathbf{n}$ & $\mathbf{X}$ & $\min$ & $\max$ & Размах вариаций \\
\hline 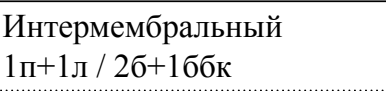 & 9 & 71,96 & 70,54 & 73,91 & $60-84$ \\
\hline Плече-бедренный $1 / 2$ & 11 & 74,16 & 72,21 & 77,14 & $68,8-72,9$ \\
\hline Луче-большеберцовый $1 / 1$ & 9 & 69,29 & 65,18 & 72,09 & $62-71$ \\
\hline Луче-плечевой $1 / 1$ & 11 & 76,46 & 74,63 & 78,42 & $71-82$ \\
\hline Берцово-бедренный $1 / 2$ & 9 & 81,52 & 78,70 & 87,19 & $77,3-86,6$ \\
\hline Ширина плеч (см) & 7 & 31,67 & 29,80 & 34,90 & \\
\hline Плече-ростовой & 7 & 21,26 & 20,27 & 22,68 & \\
\hline Ширина таза (см) & 7 & 25,83 & 24,00 & 28,40 & \\
\hline Тазовый & 4 & 76,14 & 73,15 & 78,75 & \\
\hline Тазо-ростовой & 7 & 17,34 & 16,15 & 19,32 & \\
\hline $\begin{array}{l}\text { Реконструированная } \\
\text { длина тела (см) }\end{array}$ & 10 & 149,9 см & 144,9 & 155,6 & \\
\hline
\end{tabular}

Длину тела, которая могла быть у индивидов при жизни, мы рассчитывали по трем формулам (Пирсона и Ли, Дюпертюи и Хеддена, Бунака (цит. по Алексееву 1960). Далее определялась средняя величина для каждого индивида. Разница в росте между мужчинами колеблется в пределах 10 см. Длину тела можно охарактеризовать как низкую и ниже среднего. 
Для женщин группы в целом оказалось характерным среднее относительное соотношение длины руки к ноге, согласно значениям интермембрального индекса.

Плече-бедренный указатель оказался очень высоким. Минимальная величина соответствует максимальному значению этого индекса у человека современного типа (согласно размаху вариаций, взятого из литературных источников). Таким образом, женщин отличали выраженно удлиненные плечевые отделы, согласно плече-бедренному индексу.

Значение луче-большеберцового соотношения оказалось в основном среднее, выше среднего и высокое.

Луче-плечевой (брахиальный) индекс у женщин данной группы соответствует величинам немного ниже среднего, средним и немного выше среднего. То есть, в целом, длина предплечья относительно плеча у женщин группы была средней.

Анализ берцово-бедренного, или крурального, индекса показал следующее. У большинства женщин группы этот показатель был средним и ниже среднего. Только у одной женщины величина индекса оказалась очень высокой, и еще у одной - выше среднего.

Ширина плеч оказалась очень малой у большинства индивидов. Только у одной женщины ширина плеч была немного побольше - около 35 см. Длина тела у нее была также побольше. Относительная же ширина плеч (согласно плече-ростовому индексу) у всех женщин была почти одинаковой.

Для женщин группы был также характерен довольно низкий таз средней ширины. Только у одной женщины ширина таза была чуть побольше, $-28,4$ см. У нее же относительная ширина таза (по данным тазо-ростового индекса) оказалась наибольшей.

Рассчитанная прижизненная длина тела варьирует в пределах 144,9 см - 155,6 см. таким образом, женщины группы характеризовались низким ростом.

В таблицах 7 и 8 представлены результаты расчета индексов массивности (прочности) длинных костей конечностей и некоторые другие показатели.

Таблица 7

\section{Результаты расчета индексов массивности и других показателей} длинных костей конечностей мужчин из некрополя Биели

\begin{tabular}{|c|c|c|c|c|c|}
\hline Индексы & $\mathbf{n}$ & $\mathbf{X}$ & $\min$ & $\max$ & Размах вариаций \\
\hline Ключица 6/1 & 12 & 27,86 & 24,39 & 32,26 & $20-30$ \\
\hline Плечевая 7/1 & 13 & 21,13 & 19,11 & 22,77 & $18-22$ \\
\hline Плечевая 6/5 & 13 & 84,82 & 75,00 & 95,45 & $\ldots$ \\
\hline Лучевая $3 / 1$ & 12 & 18,84 & 17,09 & 20,08 & $14-18$ \\
\hline Лучевая $5 / 4$ & 12 & 74,81 & 66,67 & 87,50 & $\ldots$ \\
\hline Локтевая 3/2 & 11 & 17,28 & 15,58 & 19,21 & $15-18$ \\
\hline Локтевая 11/12 & 12 & 78,00 & 63,16 & 93,33 & $\ldots$ \\
\hline Локтевая 13/14 & 12 & 78,77 & 72,00 & 95,65 & $\cdots$ \\
\hline Бедро 8/2 & 12 & 20,92 & 19,72 & 21,73 & $18-21$ \\
\hline Бедро 6/7 & 12 & $\ldots$ & 85,71 & 110,71 & $\ldots$ \\
\hline Бедро 10/9 & 11 & 82,72 & 67,57 & 93,94 & $\ldots$ \\
\hline
\end{tabular}


Таблица 7 (продолжение)

\begin{tabular}{l|c|c|c|c|c}
\hline Индексы & $\mathbf{n}$ & $\mathbf{X}$ & $\min$ & $\max$ & Размах вариаций \\
\hline ББК 10/1 & 12 & 24,36 & 22,39 & 25,68 & $20-22$ \\
\hline ББК 10в/1 & 12 & 22,38 & 20,97 & 24,12 & $18-23$ \\
\hline ББК 9/8 & 11 & 71,44 & 61,29 & 80,77 & $60-90$ \\
\hline ББК 9а $/ 8$ a & 12 & $\ldots$ & 60,00 & 79,41 & $\ldots$ \\
\hline
\end{tabular}

Массивность ключиц у большинства мужчин группы была выше среднего и даже высокой.

То же самое можно сказать и относительно массивности плечевых костей мужчин группы. При этом степень уплощенности тела костей посередине и соответствующий уровень развития костной основы дельтовидной шероховатости у индивидов группы сильно различаются.

Лучевые кости оказались довольно массивными и даже высоко массивными. Степень уплощенности диафиза и соответственно уровень выступания межкостного края различны.

Массивность локтевых костей в единичных случаях низкая, а в основном - выше среднего и высокая. Степень уплощенности диафиза - сильно вариабельна в данной группе. Уплощенность костей в верхней части диафиза в поперечном направлении - или низкая, или средняя. То есть в этом плане среди мужчин группы Биели были индивиды и с платоленичными локтевыми костями, и с эуроленичными. Индивидов с сильно выраженным гребнем супинатора не было.

Массивность бедренных костей у мужчин группы была средней, выше среднего и высокой. Степень уплощенности - различной. Примерно у половины индивидов кости были расширены, а задний пилястр развит слабо. У другой половины бедренные кости в середине тела были хорошо развиты сагиттально, при этом и шероховатая линия выражена очень сильно. Уплощенность верхней части диафиза оказалась различной у разных мужчин. У двух индивидов кости были очень сильно уплощены в сагиттальном направлении, или гиперплатимеричны; у четырех индивидов уплощены умеренно, или платимеричны; у пяти мужчин кости уплощены слабо, но верхний сагиттальный диаметр еще не больше поперечного (эуримеричные кости).

Большеберцовые кости отличались высокой массивностью, иногда ультравысокой. При этом уплощенность диафиза была различной. Так, большеберцовые кости четырех индивидов были сильно уплощены в поперечном направлении, или платикнемичны; у двух мужчин кости были уплощены умеренно, или мезокнемичны; у шести человек большеберцовые кости отличались расширенностью диафиза, то есть были эурикнемичными.

Степень массивности (или прочности) ключиц женщин из Биели была средняя и выше среднего.

Прочность плечевых костей варьировала от вариантов костей массивностью ниже среднего, до выше среднего и высокой. Уплощенность диафиза у большинства индивидов была слабой, только у трех женщин - выраженной. При этом дельтовидная бугристость у всех была развита довольно слабо. 
Таблица 8

Результаты расчета индексов массивности и других показателей длинных костей конечностей женщин из некрополя Биели

\begin{tabular}{|c|c|c|c|c|c|}
\hline Индексы & $\mathbf{n}$ & $\mathbf{X}$ & $\min$ & $\max$ & Размах вариаций \\
\hline Ключица 6/1 & 7 & 26,20 & 23,44 & 28,69 & $20-30$ \\
\hline Плечевая 7/1 & 11 & 20,59 & 18,64 & 23,16 & $18-22$ \\
\hline Плечевая 6/5 & 11 & 80,52 & 69,57 & 90,48 & $\ldots$ \\
\hline Лучевая 3/1 & 11 & 18,05 & 15,75 & 21,05 & $14-18$ \\
\hline Лучевая 5/4 & 11 & 71,38 & 56,25 & 78,57 & $\ldots$ \\
\hline Локтевая $3 / 2$ & 10 & 16,38 & 14,22 & 18,23 & $15-18$ \\
\hline Локтевая 11/12 & 10 & 81,56 & 68,75 & 92,31 & $\ldots$ \\
\hline Локтевая 13/14 & 10 & 83,32 & 72,73 & 94,74 & $\ldots$ \\
\hline Бедро 8/2 & 11 & 20,21 & 18,37 & 23,12 & $18-21$ \\
\hline Бедро 6/7 & 11 & $\ldots$ & 79,31 & 108,70 & $\ldots$ \\
\hline Бедро 10/9 & 11 & 79,87 & 67,65 & 93,10 & \\
\hline ББК 10/1 & 9 & 23,23 & 20,82 & 25,59 & $20-22$ \\
\hline ББК 10в/1 & 9 & 21,72 & 19,24 & 24,58 & $18-23$ \\
\hline ББК $9 / 8$ & 10 & 71,39 & 64,29 & 78,57 & $60-90$ \\
\hline ББК $9 \mathrm{a} / 8 \mathrm{a}$ & 10 & $\ldots$ & 63,33 & 77,78 & $\ldots$ \\
\hline
\end{tabular}

Лучевые кости отличались массивностью, иногда очень высокой. При этом тело костей было уплощено или очень сильно, или умеренно.

Массивность локтевых костей оказалась различной. У одних индивидов наблюдаются выраженно грацильные кости, у других средне-массивные, встречаются и индивиды с высоко массивными локтевыми костями. При этом диафиз, примерно посередине, у разных женщин был уплощен по-разному. В верхней части локтевые кости у трех женщин уплощены в поперечном направлении сильно (платоленичны); у семи женщин, то есть, у большинства, - кости умеренно расширены, или эуроленичны.

Бедренные кости по уровню прочности диафиза оказались различными: и грацильными, и средне-массивными, и массивными. В большинстве случаев диафиз в средней части уплощен в сагиттальном направлении, а шероховатая линия бедра развита слабо. Только у двух женщин бедренные кости оказались сильно уплощенными в поперечном направлении, но шероховатая линия все равно у них была выражена слабо. У трех женщин из группы Биели бедренные кости в верхнем ярусе диафиза оказались сильно уплощены в сагиттальном направлении, или гиперплатимеричными. У пяти индивидов уплощение большеберцовых костей сверху умеренное (кости платимеричные). У трех женщин бедренные кости оказались эуримеричными, то есть, достаточно слабо уплощенными сагиттально.

Большеберцовые кости подавляющего большинства женщин группы оказались массивными или даже ультра-массивными. Степень уплощенности диафиза, как и у мужчин группы, оказалась различной. У двух индивидов кости были сильно уплощены поперечно, или платикнемичными; у трех женщин кости были уплощены умеренно (мезокнемичны); у пяти индивидов (то есть, у половины женщин) кости были сильно расширены, или эурикнемичны. 


\section{Заключение}

Таким образом, в изученной нами серии крымских татар из некрополя Биели (Крым) датируемой XVII - началом XVIII веками, нами было изучено 94 индивида.

Палеодемографический анализ выявил относительное неблагополучие группы.

Краниологический анализ показал, что мужская часть выборки брахикранная, со средней высотой лица, с хорошей горизонтальной профилировкой лицевого скелета и низкими орбитами. Женская часть выборки характеризуется брахикранией, средней высотой лица с ослабленной горизонтальной профилировкой лицевого скелета и широким носом.

Остеологическое исследование выявило высокую вариабельность группы по показателям пропорций конечностей, ширине плеч и таза. Можно отметить относительную удлиненность проксимального отдела руки, согласно плече-бедренному индексу. Прижизненная длина тела мужчин и женщин была ниже среднего и низкой.

Массивность костей и рук и ног у мужчин была высокой, у женщин массивными и ультра-массивными оказались только ключицы, лучевые и большеберцовые кости. Остальные кости по степени прочности были вариабельны. По другим показателям кости конечностей мужчин и женщин также были разнообразны.

\section{Научная литература}

Алексеев В.П., Дебеи Г.Ф. Краниометрия. Методика антропологических исследований. М.: Наука, 1964.

Алексеев В.П. Остеометрия. М.: Наука, 1966.

Богатенков Д.В. Палеодемография Мистихали. // Т.И. Алексеева, Д.В. Богатенков, Г.В. Лебединская. Влахи. Антропо-экологическое исследование (по материалам средневекового некрополя Мистихали). М., 2003. С.19-49.

Васильев С.В. К краниологии крымских татар. // Вестник антропологии. 2018. № 4 (44). С. 27-33.

Васильев С. В., Боруикая С. Б. Краниологическое исследование крымско-татарского некрополя Бахчи-Эли XIX-XX вв. // Известия Иркутского государственного университета. Серия

Геоархеология. Этнология. Антропология. 2018. Т. 26. С. 146-153.

Добряк В.И. Судебно-медицинская экспертиза скелетированного трупа. Киев: Госмедиздат УССР. 1960.

Иванов А.В., Васильев С.В. Краниологическая характеристика позднесредневековых крымских татар: по материалам некрополя у с. Батальное. // Вестник антропологии. 2019. № 4 (48). С.243-251.

Пашкова В.И. Определение пола и возраста по черепу. Ставрополь, 1958.

Пашкова В. И. Очерки судебно-медицинской остеологии. Ставрополь, 1963.

Borutskaya, Svetlana B., Vasilyev, Sergey . * $^{*}$

\section{Reconstruction of the physical type of the late medieval Crieman Tatars of the Kerch Peninsula}

DOI: $10.33876 / 2311-0546 / 2020-52-4 / 269-281$

The article provides a comprehensive paleoanthropological analysis of the population from the Bieli necropolis (Kerch, Republic of Crimea). This sample is of great interest in connection with the study of the Crimean Tatars ethnogenesis. The work features a craniological characteristic of the late medieval Crimean Tatars and reconstructions of the face based on the skull by the method of M.M. Gerasimov. Particular attention is paid to 
the reconstruction of the physical appearance of a given population. High infant mortality and a low indicator of the average life expectancy of the population were revealed, which reflects general low well-being in the studied group.

Key words: Crimean Tatars, craniometry, osteometry, paleodemography

* Borutskaya, Svetlana B. - PhD in biol., Moscow state University. M. V. Lomonosova (Moscow, Russia).E-mail: vasbor1@yandex.ru

Vasilyev, Sergey V. - Institute of Ethnology and Anthropology, RAS (Moscow, Russia). E-mail: vasbor1@yandex.ru

The research was supported by the Russian Foundation for Basic Research (RFFI, project No. 18-0900429)

\section{References}

Alekseev, V.P., and G.F Debets. 1964. Kraniometriia. Metodika antropologicheskikh issledovanii. [Craniometry. Methods of anthropological research]. Moscow: Nauka.

Alekseev, V.P. 1960. Osteometriya. [Osteometry] Moscow: Nauka.

Bogatenkov, D.V. 2003. Paleodemografiya Mistixali. [Paleodemography Mistihali]. Vlaxi. Antropoekologicheskoe issledovanie (po ma-terialam srednevekovogo nekropolya Mistixali) [Vlachi. Anthropo-ecological research (based on materials from the medieval necropolis of Mistihali)], edited by T.I. Alekseeva, D.V. Bogatenkov, G.V. Lebedinskaya, 19-49. Moscow.

Vasilyev, S.V. 2018. K kraniologii krymskix tatar. [On the craniology of the Crimean Tatars] // Vestnik antropologii 4 (44): 27-33.

Vasilyev, S.V., and S.B. Boruczkaya. 2018. Kraniologicheskoe issledovanie kry`msko-tatarskogo nekropolya Baxchi-E'li XIX-XX vv. [Craniological study of the Crimean Tatar necropolis of Bakhchi-Eli, XIX-XX centuries]. Izvestiya Irkutskogo gosu-darstvennogo universiteta. Seriya Geoarxeologiya. E'tnologiya. Antropolo-giya 26: 146-153.

Dobryak, V.I. 1960. Sudebno-medicinskaya ekspertiza skeletirovannogo trupa. [Forensic examination of a skeletonized corpse]. Kiev: Gos-medizdat USSR.

Ivanov, A.V., and S.V. Vasilyev. 2019. Kraniologicheskaya xarakteristika pozdnesred-nevekovyx krymskix tatar: po materialam nekropolya u s. Batalnoe. [Craniological characteristics of the Late Middle Ages Crimean Tatars: based on the materials of the necropolis near the village. Battle]. Vestnik antropologii 4 (48): 243-251.

Pashkova, V.I. 1958. Opredelenie pola $i$ vozrasta po cherepu. [Determination of gender and age from the skull]. Stavropol.

Pashkova, V.I. 1963. Ocherki sudebno-medicinskoj osteologii. [Essays on forensic medical osteology]. Stavropol. 